\title{
V. On the sugar of the eucalyptus
}

\author{
James F.W. Johnston Esq. M.A. F.R.S.
}

To cite this article: James F.W. Johnston Esq. M.A. F.R.S. (1843) V. On the sugar of the eucalyptus, Philosophical Magazine Series 3, 23:149, 14-16, DOI: $10.1080 / 14786444308644684$

To link to this article: http://dx.doi.org/10.1080/14786444308644684

$$
\text { 册 Published online: } 30 \text { Apr } 2009 .
$$

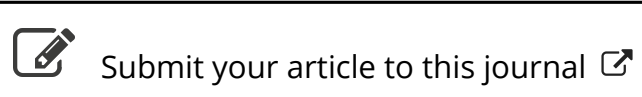

\footnotetext{
Џ Article views: 3
}

Q View related articles $\sqsubset$ 


\section{Professor Johnston on the Sugar of the Eucalyptus.}

But $V$ will not serve for the equations of the disturbing body. If we wish to find integral equations of the first order, we should have a perturbating function which will serve for two at least of the three sets of equations (A.).

My paper on M. Jacobi's Theory of Elliptic Functions, printed in the Number of this Journal for the present month, is not very intelligible. I wish, therefore, to subjoin a few words in the hope of making it plainer. The expressions sin $a m n \omega, \cos a m n \omega$, mean sine of amplitude of $n \omega$, cosine of amplitude of $n \omega$. So also s $a u$, c $u u$ mean sine and cosine of the amplitude of $u$. They should have been printed thus :$\sin$ am $n \omega, \cos$ am $n \omega, \mathrm{s} a u, \mathrm{c} a u$. These faults run through the paper. Moreover the $a m$ and $a$ for amplitude should not have been in italics, as italics appear to denote quantity only. Denby, near Huddersfield, April 11, 1843.

V. On the Sugar of the Eucalyptus.

By James F. W. Johnston, Esq., M.A., F.R.S.*

IN Van Diemen's Land a species of sugar or manna falls in drops or rounded opaque tears from several species of Eucalyptus. This is collected in considerable quantity, but it is doubtful still I believe whether it is a natural exudation of the trees from which it falls, or, like the different kinds of honey-dew in our own country, is the consequence of punctures made by insects.

I am indebted for a portion of this manna to Sir W. Jackson Hooker, to whom also I owe the above information regarding its origin. It is soft, slightly yellowish, opaque, is inferior in sweetness to cane-sugar or to ordinary manna, and is in small, rounded, slightly cohering masses. Æther extracts from it only a minute portion of wax, alcohol leaves behind only a small quantity of gum, while water dissolves it without sensible residue.

The aqueous solution crystallizes on evaporation in minute radiating prisms and prismatic needles which form rounded masses having a crystalline structure. It is obtained however from water in distinct crystals with much greater difficulty. than from its solution in ordinary alcohol. In boiling alcohol it dissolves in considerable quantity, and is in a great measure precipitated in beautiful white but minute prismatic crystals as the solution cools. It not unfrequently deposits itself also in the form of a white hard and solid crust on the bottom and sides of the bottle into which the hot solution is filtered.

This sugar as it crystallizes from the alcoholic solution has

* Communicated by the Chemical Society; baving been read December 20,1842 . 
the same constitution as grape-sugar, $\mathrm{C}_{12} \mathrm{H}_{14} \mathrm{O}_{14}$, or $\mathrm{C}_{24}$ $\mathrm{H}_{28} \mathrm{O}_{28}$, but it differs from grape-sugar in its appearance, in its relations to alcohol as above described, in the ease with which it can be obtained in a pure crystallized form, and in its relations to heat.

When suddenly heated at once to $200^{\circ}$ or $212^{\circ}$, it melts and loses 5 atoms of water, wherens grape-sugar loses only four. But if it be first gradually heated and kept for two or three hours at $180^{\circ}$ only, it will part with seven atoms of water without melting. In that respect it resembles a salt, which if heated suddenly will melt in its water of crystallization, but by a cautious regulation of the heat may be dried without undergoing fusion. If once melted, this sugar may be kept for several hours at $212^{\circ}$ without losing much more than the five atoms, and it must be raised to $240^{\circ}$ or $250^{\circ}$ before it parts with the whole seven, and in every case in which I have made the experiment has even assumed a brown colour, owing to incipient decomposition before the seven atoms have been altogether removed.

When the seven atoms have been driven off by a heat not higher than $200^{\circ}$, the dry powder may be heated to $280^{\circ}$, when it begins to fuse, and may be kept for several hours at $300^{\circ}$ without further loss or any change of colour.

After being thus heated the sugar attracts moisture rapidly from the air, and if left over night in a damp room it will assume the form of transparent globules of syrup, which gradually crystallize into colourless radiated masses having the original weight of the portion of sugar experimented upon. We may conclude therefore that the seven atoms are altogether water of crystallization.

When mixed with oxide of lead moistened with water and then gradually dried and heated to $300^{\circ}$, it appeared to lose two additional atoms of water without undergoing decomposition; but when exposed to the air on cooling, the mixture rapidly attracts water again from the air. When this mixture after thus heating is boiled with distilled water and thrown upon the filter, a solution of sugar passes through in which hydrosulphurets detect no trace of lead.

The following formulæe exhibit the constitution of this sugar and the loss of weight it undergoes at different temperatures:-

Crystallized sugar before 7 ment, per cent. or after heating. . . $\} \mathrm{C}_{24} \mathrm{H}_{21} \mathrm{O}_{21}+7 \mathrm{HO}$

Fused at $212^{\circ}$ to $220^{\circ} \cdot \mathrm{C}_{24} \mathrm{H}_{21} \mathrm{O}_{21}+2 \mathrm{HO} \quad 11.23$

$\left.\begin{array}{l}\text { Dried without fusion be- } \\ \text { tween } 180^{\circ} \text { and } 300^{\circ}\end{array}\right\} \mathrm{C}_{24} \mathrm{H}_{21} \mathrm{O}_{21}$ 
Loss by experiment, per cent.

$\left.\begin{array}{l}\text { Dried at } 260^{\circ} \text { to } 300^{\circ} \\ \text { with oxide of lead. }\end{array}\right\} \mathrm{C}_{24} \mathrm{H}_{19} \mathrm{P} b_{2} \mathrm{O}_{21}$ ?
$\left.\begin{array}{c}\text { This again exposed to } \\ \text { the air became. . }\end{array}\right\} \mathrm{C}_{24} \mathrm{H}_{19} \mathrm{P} b_{2} \mathrm{O}_{21}+7 \mathrm{HO}$ ?

$20 \cdot 82$ ?

This sugar, in its relations to alcohol, in the ease and readiness with which it crystallizes from an alcoholic solution, and in the appearance of its crystals, has much resemblance to manna-sugar (Mannite). It is more soluble however in boiling alcohol than mannite, and is therefore obtained in larger quantity on the cooling of the alcohol in which it has been dissolved by the aid of heat. Mannite also, if heated gradually, may be raised to $300^{\circ}$ (I do not know how much higher) without either melting or undergoing any loss of weight.

Eucalyptus-sugar gives a precipitate of a slightly brownish tinge with caustic baryta; and a white precipitate is also obtained by mixing it with a solution of ammoniacal trisacetate of lead. This salt of lead I am at present preparing for analysis, and I hope to have the honour of submitting the results to the Society at a future meeting. In the mean time the formulæ presented in this notice must be considered as open to correction.

VI. On Palladium-Its Extraction, Alloys, \&c. By William John Cock, Esq.*

THIS metal was discovered by Dr. Wollaston in the year $11803 \mathrm{t}$, as one of the alloys of native platinum, which for some time after this discovery appears to have been considered the only source of palladium; and as the quantity of the latter metal so alloying the native platinum is very small, it was then considered as a very rare metal: of late ycars, however, the importation into this country from Brazil of gold dust, alloyed with palladium, has occasioned a much more extensive supply of this metal, as it exists in some specinens of gold dust to the extent of 5 or 6 per cent., and in one instance (that of the gold from the Candonga mine) it constitutes the only alloy of the gold.

The operation of refining is conducted in the following manner:- The gold dust is fused in charges of about 7 lbs.

* Communicated by the Chemical Society; having been read January 3,1843 .

+ Dr. Wollaston's original paper on Palladium, reprinted from the Philosophical Transactions, will be found in Phil. Mag. S. 1. vol. xx. p. 163 ; see also vol. xv. p. 287.-EDit. 